\title{
Independence of forensic science
}

The third appeal of six people against life sentences imposed 15 years ago raises sombre questions about the management of forensic services, not to mention the quality of British justice.

THE application of scientific techniques to the detection of crime and the conviction of criminals has a long and even a spectacular history, with the result that the achievements of forensic science have spawned a whole genre of airport fiction. But real life, usually less glamorous, is full of pitfalls for the unwary. So much is plain from the third re-hearing now under way by the British Appeal Court of the evidence for the conviction in 1975 of six Irishmen for having killed 24 people (and injured more than 120) by exploding a bomb in a crowded drinking-house in Birmingham. The 'Birmingham six', as they are known, were convicted and imprisoned for life on evidence of two kinds: purported confessions to the police who had arrested them and evidence (accepted by the trial court as valid) that two of them had been found on forensic investigation to have traces of explosives on their right hands.

What now emerges is that the forensic evidence presented at the original trial was flawed, and has for practical purposes been withdrawn. A chemical procedure for identifying nitroglycerine has now been found to have been inadequately controlled: materials other than nitroglycerine (including soap) can yield positive results. Results of an investigation by gas chromatography, potentially a more sensitive technique, were acknowledged in evidence last week to be similarly capable of confusion by other materials (and, even so, were positive for the left hand of only one of the two supposedly contaminated defendants). But forensic science has salvaged some of its reputation by producing evidence (still formally to be accepted by the Appeal Court) that the disputed confessions produced by the police consisted of writings (by the interrogating officers) that were neither contemporaneous nor consecutive.

Two important issues stem from these alarming disclosures, of which the chief is more than a mere embarrassment to the British government and judicial system. If, as seems probable, the Birmingham six are now released after 16 years in jail, this will be yet another case in which zealous and overzealous policemen have been prepared to concoct evidence in the pursuit of a conviction. That many of these cases have involved supposed terrorism by the Irish Republican Army has not, to say the least of it, simplified the management of Ulster's problems.

The forensic issue is, or should be, more tractable. In Britain, the Forensic Science Service has traditionally been run by the Home Office as a common service for Britain's police forces. But from 1 April, it will become an executive agency - expected to pay its way but not to make a profit. The forensic service, which has six laboratories south of the Scottish border, will take business from all potential customers: police forces, but also defendants before the courts. The danger is that the service will be yet more dependent on the wishes of its customers, includinge policemen out for a conviction.

That is why a still more radical change is required. It was claimed (by counsel for the appellants) at last week's hearing that evidence that the original test for nitroglycerine was not reproducible had been withheld from the trial court - and from defence.lawyers. It is only fair (to the forensic service 15 years ago) to acknowledge that the court might have learned the truth if the defence lawyers had asked the right questions (and only fair to them to acknowledge that lawyers are rarely trained in the niceties of laboratory technique).

Yet there can be few occasions when the results of forensic investigations are as clear-cut as the airport literature would have the rest of us believe, let alone when lawyers appreciate what the uncertainties of forensic investigations mean. So much has been well illustrated by the arguments over the unreflective use of DNA fingerprinting by some US courts (see Nature 339, 501; 1989). The only durable solution is that forensic services everywhere should become the servants of the courts at which their evidence is presented, not of those who commission their investigations.

In British circumstances, the simple solution is that they should be a child of the Crown Prosecution Service, which has (among other things) responsibility for investigating the quality of evidence against accused persons. That is the solution advocated by Lord Scarman, Britain's most distinguished ex-judge. But why not go further, and make them dependent on the courts as such, as are the bailiffs who go about collecting debts? The snag, for the government, would be that the prospect that the forensic services would be selffinancing might then melt away, but when the reputation of the judicial system has been undermined by faulty evidence, that hardly seems a substantial consideration.

\section{Technology untied?}

Plans to liberalize British telecommunications would be more commendable if they were more radical.

SiNCE Soon after the time of Alexander Graham Bell, govern- 